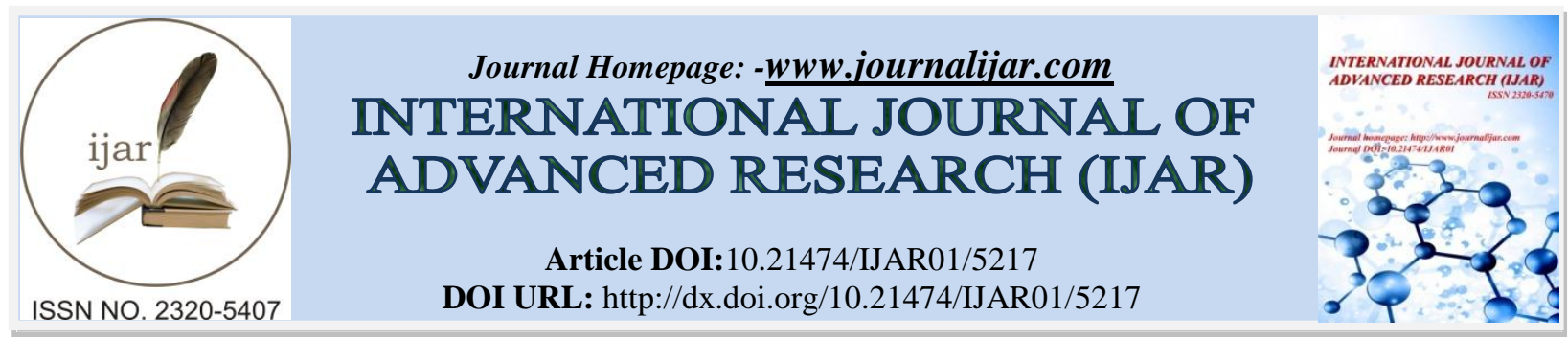

RESEARCH ARTICLE

\title{
EFFECT OF CHROMIUM AND CADMIUM TOXICITY ON BIOCHEMICAL PARAMETERS OF SPIRODELLA POLYRHIZA.
}

\author{
Rifat Ara Wani ${ }^{1}$, Bashir A Ganai ${ }^{1}$, Manzoor A Shah ${ }^{2}$ and Fayaz Ahmad Bhat ${ }^{1}$. \\ 1. Department of Environmental Science / Centre of Research for Development, University of Kashmir, Srinagar \\ 190006, J\&K, India. \\ 2. Department of Botany, University of Kashmir, Srinagar-190006, J\&K, India.
}

\section{Manuscript Info \\ Manuscript History \\ Received: 19 June 2017 \\ Final Accepted: 21 July 2017 \\ Published: August 2017}

Keywords:-

Heavy metals, Macrophytes,

Spirodellapolyrhiza, Carbohydrate,

Protein.

\section{Abstract}

Chromium and cadmium the most toxic metals in the earth's crust can cause severe damage to plants like growth inhibition and even death. The purpose of this study was to evaluate the effect of different concentrations of $\mathrm{Cr}$ and $\mathrm{Cd}(0 \mathrm{ppm}, 2 \mathrm{ppm}, 4 \mathrm{ppm}$ and $6 \mathrm{ppm})$ on the biochemical parameters (total protein, total lipid and total carbohydrate contents of free floating aquatic plant- Spirodellapolyrhiza. These parameters were calculated at the end of the experiment by colorimetric method. The results revealed that total protein content of the selected macrophytes was higher at low concentrations but decreased thereafter while the total lipid and total carbohydrate content decreased as the concentration of $\mathrm{Cr}$ and $\mathrm{Cd}$ increased in the external medium. Perusal of data revealed thatthe toxic effects of $\mathrm{Cr}$ and $\mathrm{Cd}$ are directly proportional to their concentrations.

Copy Right, IJAR, 2017,. All rights reserved.

\section{Introduction:-}

Increasing anthropogenic activities are considered as leading causes of environmental deterioration and pollution. Among various environmental contaminants, heavy metals are of particular concern because of their potential toxic effect, non-biodegradable nature and ability to bio-accumulate in aquatic ecosystems (1). Heavy metals are potentially hazardous pollutants, and are different from other pollutants as they cannot be biologically degraded, but are only transformed from one oxidation state to another (2). Heavy metals like $\mathrm{Zn}, \mathrm{Fe}, \mathrm{Cu}, \mathrm{Mn}$ are essential for plant growth and important constituents of many enzymes of metabolic importance.Other metals like $\mathrm{Pb}, \mathrm{Cd}, \mathrm{As}, \mathrm{Se}$, $\mathrm{Cr}$ and $\mathrm{Al}$ are biologically non-essential and toxic above certain threshold levels. $\mathrm{Cr}$ and $\mathrm{Cd}$ affect all elements of the food chain, from soil microorganisms to plants, animals and humans once they enter the natural environment (3).

Chromium ( $\mathrm{Cr}$ )- the critical environmental contaminant found abundantly in the earth's crust adulterate the environment. Although, $\mathrm{Cr}$ is toxic but it has some nutritive importance as well (4).Among various valence states, $\mathrm{Cr}$ (III) and $\mathrm{Cr}$ (VI) are the highly stable forms of $\mathrm{Cr}$ (5). The toxicity of $\mathrm{Cr}$ (VI) compounds is higher than that of $\mathrm{Cr}$ (III) and mutagenicity is an exclusive characteristic of $\mathrm{Cr}$ (VI) compounds (6). $\mathrm{Cr}$ is phytotoxic either at all concentrations or above certain threshold levels(7). $\mathrm{Cr}$ accumulation in plants causes high toxicity in terms of reduction in growth and biomass accumulation and induces structural alterations. 
Cadmium $(\mathrm{Cd})$ is the most fatal metal and is characterized byhigh stability and toxicity. The non-degradable property of Cd allows itto stay in circulation when it is released to the environment (8). The predetermined course of Cd is in water bodies when it is released from industrial wastewater treatment plants $[9,10]$. The peculiar characteristics of Cdare that it is an odorless, silver-white, blue -tinged or grayish- whitepowder, having an atomic weight of 112.4 and other distinguishing featureis the oxidation sate of +2 in all its compounds. Cadmium leads to oxidative stress when it bindswith essential respiratory enzymes [11]. Cadmium is a non-essential element and can be strongly phyto-toxic to aquatic organisms (12).

Few plant species are able to accumulate high amount of $\mathrm{Cr}$ and $\mathrm{Cd}$ without being damaged. Aquatic macrophytes, whether free-floating, submerged or emergent have been known to possess the ability to sequester heavy metals (13, 14). Such Cr-tolerant, hyperaccumulator plants are exploited for their bioremediation property.

The aim of this study was to determine $\mathrm{Cr}$ and $\mathrm{Cd}$ toxicity on biochemical parameters of a free floating aquatic macrophyte- S. polyrhiza.

\section{Materials and Methods:- Plant material:-}

S. polyrhiza, commonly known as green duckweed, is a small, free floating perennial aquatic plant belonging to the Lemnaceae family. Duckweed species are used in waterquality studies for monitoring heavy metals (15) and are considered as better alternative and have been recommended for wastewater treatment because they are more tolerant, easily harvestable and capable of rapid growth (16).

\section{Culture media and plant sampling:-}

Aquatic macrophyte was collected from Dal Lake and transferred to the laboratory in polyethylene bags, washed several times with tap and deionised water to remove adhering soil. Plants of similar size and height were selected and acclimatized to the growth conditions for a week prior to the experiment in clean water.

For preparation of culture media (hydroponics) lake water was used directly. Chemical composition of the lake water (Table 1) was analyzed before using it for preparation of culture media.

Table 1:-Chemical composition of lake water.

\begin{tabular}{|l|c|}
\hline \multicolumn{1}{|c|}{ Parameters } & Results of chemical analysis \\
\hline $\mathrm{pH}$ & 7.2 \\
\hline Dissolved Oxygen $\mathrm{mg} / \mathrm{L}$ & 7.9 \\
\hline Total Hardness $(\mathrm{as} \mathrm{CaCO} 3), \mathrm{mg} / \mathrm{L}$ & 241 \\
\hline Calcium content $(\mathrm{Ca}), \mathrm{mg} / \mathrm{L}$ & 182 \\
\hline Magnesium $(\mathrm{Mg}), \mathrm{mg} / \mathrm{L}$ & 14.34 \\
\hline Sodium $(\mathrm{Na}), \mathrm{mg} / \mathrm{L}$ & 8.0 \\
\hline Potassium $(\mathrm{K}), \mathrm{mg} / \mathrm{L}$ & 1.5 \\
\hline Chloride $(\mathrm{Cl}), \mathrm{mg} / \mathrm{L}$ & 4.1 \\
\hline Total nitrogen, $\mu \mathrm{g} / \mathrm{L}$ & 2720 \\
\hline Total-phosphorus, $\mu \mathrm{g} / \mathrm{L}$ & 240 \\
\hline Cadmium $(\mathrm{Cd}), \mathrm{mg} / \mathrm{L}$ & $* \mathrm{BDL}$ \\
\hline Chromium $(\mathrm{Cr}), \mathrm{mg} / \mathrm{L}$ & $* \mathrm{BDL}$ \\
\hline
\end{tabular}

*BDL- Below Detection level

All parameters listed above were measured according to the Standard Methods for the Examination of Water and Wastewater as prescribed by American Public Health Association, 2005 methods.

Then the desired amounts of cadmium chloride $\left(\mathrm{CdCl}_{2} \cdot 2 \mathrm{H}_{2} \mathrm{O}\right)$ and potassium dichromate $\left(\mathrm{K}_{2} \mathrm{Cr}_{2} \mathrm{O}_{7}\right)$ salts were dissolved in distilled water separately to achieve the appropriate contamination levels of $\mathrm{Cd}$ and $\mathrm{Cr}$ respectively. Working metal and standard solutions with different concentrations of each metal (2.0, 4.0 and $6.0 \mathrm{ppm})$ were prepared by diluting the corresponding stock solution $\left(1000 \mathrm{mgL}^{-1}\right)$ using deionized water. After the adaptation period, acclimatized plant samples ( $25 \mathrm{~g}$ ) were transplanted to the clear culture enclosures (diameter $8 \mathrm{~cm}$, height 15 $\mathrm{cm}$, volume 5L). These plants were grown in experimental enclosures known as treated enclosures containing metal $(\mathrm{Cd}$ and $\mathrm{Cr})$ spiked lake water under natural conditions. A control setup was also established known as untreated 
enclosures (where same amount of plant samples were cultured in lake water but without addition of contaminants). The experiment was conducted in triplicates (i.e. comprising of 3 containers for each concentration). The contaminated water was continuously aerated with an aquarium air pump. During the experimental period average temp was about $\left(25 \pm 2^{0} \mathrm{C}\right)$. The experiment continued for 28 days. At the end of the experimental period, the plant samples were harvested from each enclosure, washed three times with deionized water and analyzed for various biochemical parameters i.e total proteins, total carbohydrates and total lipids. Total carbohydrate content of the plant species was determined colorimetrically by phenol -sulphuric acid method (17) after extraction with ethanol, total protein content of plants was determined colorimetrically by Lowry's method (18) after the extraction of proteins with distilled water and total lipid content of the plants was determined colorimetrically by Sulphophospho-Vanillin Method (19) after extraction in buffer solution of $\mathrm{pH}-7$. The results were expressed as percentage fresh weight of plants.

\section{Results and Discussion:-}

Aquatic macrophytic species cultured in experimental enclosures was compared for it biochemical parameters. Fresh plants were analyzed in order to get an insight into the variations in the biochemical parameters in different contaminants.

The results in the present study showed an increase in protein content at low concentrations but decreased with elevated heavy metal concentrations. The protein content showed a maximum increase of $30.34 \%$ of the control at concentration of $4 \mathrm{ppm} \mathrm{Cd}$ and a maximum reduction of $19.72 \%$ at $6.0 \mathrm{ppm} \mathrm{Cr}$ concentration (Fig 1).

The results obtained during the present study corroborate with the findings of 20,21 and 22 . The increase in total protein content under heavy metal stress might be related to the increase of the stress proteins synthesis such as enzymes involved in krebs cycle, glutathione and phytochelatin synthesis and also some heat shock proteins $(23,24$, 25). However, reduction in total proteins might be due to degradation by proteases (22), structural and functional modifications by the denaturation and fragmentation of proteins due to toxic effects of reactive oxidative stress (26). The most decrease was observed in Cr treatments. Cr causes metabolic alterations in exposed plants which have been described in plants either by effect on enzymes or by its ability to generate reactive oxygen species, which may cause oxidative stress $(27,28)$

Total lipid content in the present study decreased with increase in $\mathrm{Cr}$ and $\mathrm{Cd}$ concentration in the culture media. In $S$. polyrrhiza, the lipid content showed a maximum value of $(2.41 \pm 0.55) \mathrm{mg} \%$ in control and minimum value of $1.09 \pm 0.05 \mathrm{mg} \%$ at $6.0 \mathrm{ppm} \mathrm{Cd}$ concentration. The greater reduction of $54.77 \%$ was found in case of $\mathrm{Cd}$ at $6 \mathrm{ppm}$ concentration and in case of $\mathrm{Cr}$ the maximum reduction $(50.62 \%)$ was also registered at 6 ppm (Fig 2). Heavy metal toxicity to lipids might be due to oxidative damage (by generating reactive oxygen species- ROS) which can cause lipid peroxidation, membrane damage and leakage with fatty acid in membrane lipid bilayer (29, 30, 31). The results obtained in the present study are in line with works of $(32,33,34,35)$. Changes in the total lipids, reported to be an adaptive response to different environmental stresses, in order to restore optimum physical membrane properties $(36,37)$.

Total carbohydrate contents in the cultured macrophytes manifested a dose dependent relationship when exposed to different concentrations of heavy metals ( $\mathrm{Cr}$ and $\mathrm{Cd}$ ). Total carbohydrate content in S.polyrrhizashowed a maximum decrease from $16.28 \mathrm{mg} \%$ (control) to $4.29 \mathrm{mg} \%$ when exposed to $6.0 \mathrm{ppm} \mathrm{Cr}$ concentration and a minimum decrease (from $16.28 \mathrm{mg} \%$ to $13.64 \mathrm{mg} \%$ ) at $2.0 \mathrm{ppm} \mathrm{Cd}$ concentration. The maximum reduction of $73.65 \%$ was observed at $6.0 \mathrm{ppm} \mathrm{Cr}$ (Fig 3).Decrease in carbohydrate content might be attributed to the fact that during low photosynthetic production, the growth and development of plant is supported by stored carbon content in plant tissues (38), photosynthetic inhibition or stimulation of respiration rate (39). Our results corroborate with findings of $(39,40)$. Cr stress is one of the important factors that affect the photosynthesis, $\mathrm{Co}_{2}$ fixation, electro transport, photophosphorylation and enzyme activities (41). 


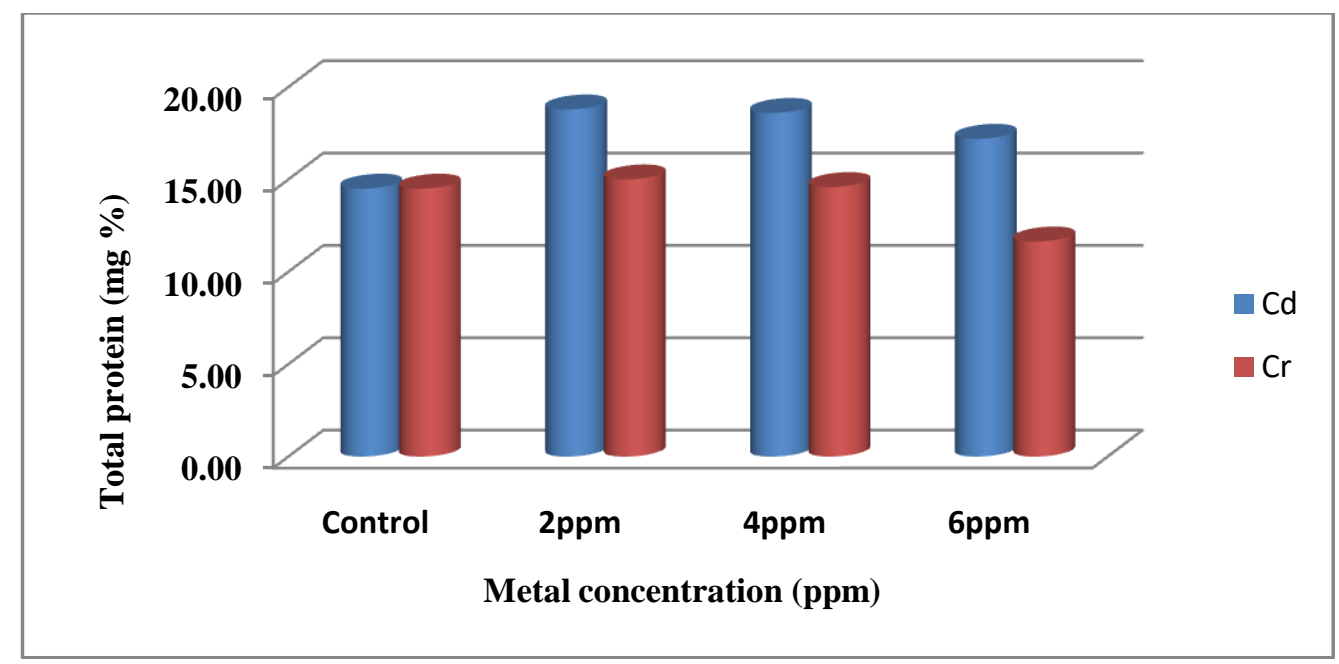

Fig 1:-Cdand Cr toxicity on total protein content of S. polyrhiza.

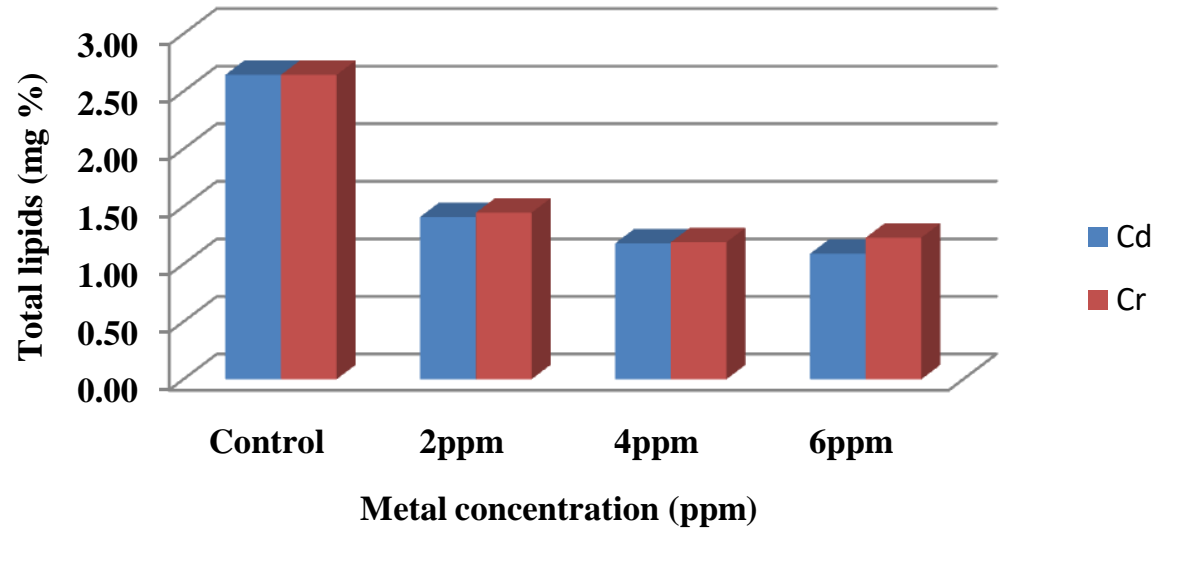

Fig 2:-Cd and Cr toxicity on total lipid content of S. polyrhiza.

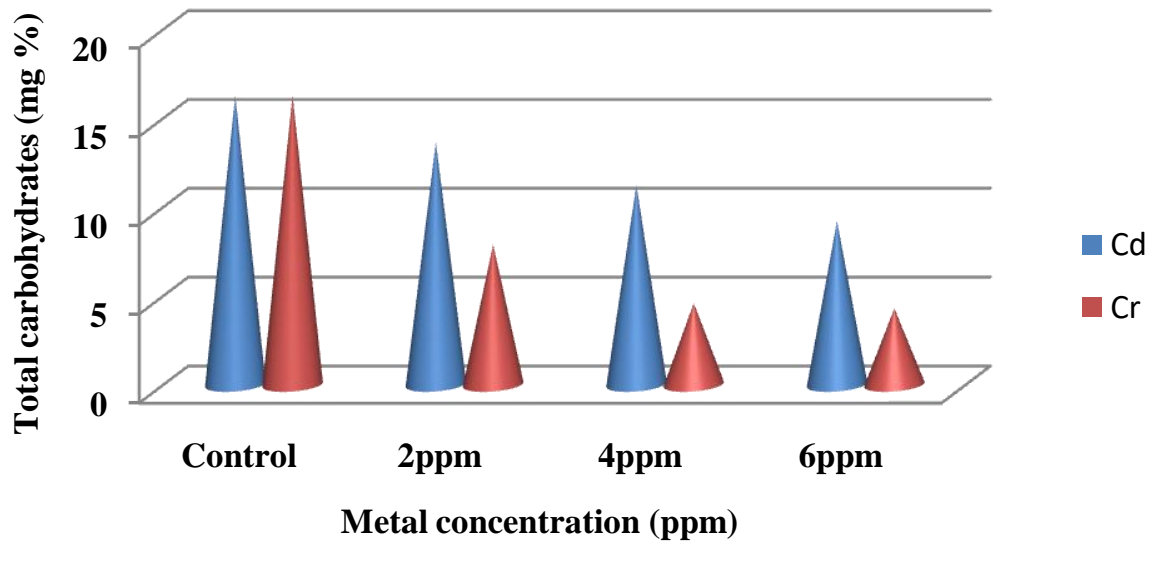

Fig 3:-Cd and $\mathrm{Cr}$ toxicity on total carbohydrate content of S. polyrhiza. 


\section{Conclusion:-}

From the above discussion, it has been found that $\mathrm{Cr}$ and $\mathrm{Cd}$ effect all the studied parameters especially at the higher concentrations but $\mathrm{Cr}$ is found more toxic than $\mathrm{Cd}$ that induces toxicity in plants at biochemical levels. Perusal of the data revealed thatthe impact of $\mathrm{Cr}$ and $\mathrm{Cd}$ toxicity in $\mathrm{S}$. polyrhiza are directly proportional to their concentrations in the culture media.

\section{Acknowledgement:-}

The authors are highly thankful to Head, Department of Environmental Science University of Kashmir for providing necessary lab facilities and support.

\section{References:-}

1. Censi P, Spoto SE, Saiano F, Sprovieri M, Mazzola S, Nardone G, Di Geronimo SI, Puntu R, Ottonello D. 2006. Heavy metals in coastal water system. A case study from the North Western Gulf of Thailand. Chemosphere. 64(7):1167-1176.

2. Gisbert C, Ros R, Deharo A, Walker DJ, Pilarbernal M, Serrano R, Navarro-Avino J 2003. A plant genetically modified that accumulates $\mathrm{Pb}$ is especially promising for phytoremediation. Biochem. Biophys. Res. Commun. 303:440-445.

3. Turkdogan MK, Kilicel F, Kara K, Tuncer L, Uygan I 2003. Heavy metals in soil, vegetables and fru its in the endemic upper gastrointestinal cancer region of Turkey. Environ ToxicolPharmacol 13(3):175-179.

4. Kabata-Pendias A, Pendias H. 2001. Trace elements in soils and plants, 3rd edn. CRC Press Inc, Boca Raton, FL, p 413.

5. Razic S, Dogo S. 2010. Determination of chromium in Menthapiperita L. and soil by graphite furnace atomic absorption spectrometry after sequential extraction and microwave-assisted acid digestion to assess potential bioavailability. Chemosphere. 78: 451-456.

6. Banks MK, Schwab AP, Henderson C. 2006. Leaching and reduction of chromium in soil as affected by soil organic concentration and plants. Chemosphere. 62:255-264.

7. Flegal R, Last J, McConnell E, Schenker M, Witschi H. 2001. Scientific review of toxicological and human health issues related to the development of a public health goal for Chromium (VI), Report prepared for the chromate toxicity review committee. p. 6.

8. Wani RA, Ganai BA, Shah MA, Uqab B. 2017. Heavy Metal Uptake Potential of Aquatic Plants through Phytoremediation Technique - A Review. J BioremediatBiodegrad. 8: 404. doi: 10.4172/2155-6199.1000404

9. Denise P, Higham P, Sadler J, Michael D. 1989. Cadmium Resistance in Pseudumunasputida: Growth and Uptake of Cadmium. J General Microbiol. 131: 2539-2544.

10. Ajmal M, Mohammad A, Yousuf R, Ahmad A. 1998. Adsorption behaviour of cadmium, zinc, nickel and lead from aqueous solution by Mangiferaindicaseed shell. Indian J Environ Health. 40: 5-26.

11. Nies DH. 2003. Efflux mediated heavy metal resistance in prokaryotes. FEMS Microbiol Rev. 27: 313-339.

12. Kuzovkina YA, Knee M, Quigley MF. 2004. Cadmium and copper uptake and translocation in five Willow (Salix L.) species. Int J Phytoremed. 6 (3):269-287.

13. Singh D, Tiwari A, Gupta R. 2012. Phytoremediation of lead from wastewater using aquatic plants Journal of Agricultural Technology. 8(1): 1-11.

14. Sbihi K, Cherifi O, El gharmali A, Oudra B, Aziz F. 2012. Accumulation and toxicological effects of cadmium, copper and zinc on the growth and photosynthesis of the freshwater diatom Planothidiumlanceolatum (Brébisson) Lange-Bertalot: A laboratory study. J Mater. Environ. Sci. 3 (3): 497-506.

15. Radic S, Stipanicev D, Cvjetko P, Mikelic IL, Rajcic MM, Sirac S, Kozlina BP, Pavlica M. 2010. Ecotoxicological assessment of industrial effluent using duckweed (Lemna minor L.) as a test organism. Ecotoxicol 19 (1):216-222.

16. Sharma SS, Gaur JP. 1995. Potential of Lemnapolyrrhiza for removal of heavy metals. EcolEng 4(1):37-43.

17. Dubois M, Gilles KA, Hamilton JK, Rebers PA, Smith F. 1956. Colorimetric method for the determination of sugar and related substances. Anal. Chem. 28: 350 - 356.

18. Knight JA, Anderson S, Rawle JM. 1972. Chemical basis of the sulfo-phosphovanillin reaction for estimating total serum lipids. Clin. Chem. 18(3): 199-202.

19. Lowry OH, Rosebrough NJ, Fait AL, Randall RJ. 1951. Protein measurement with Folin - phenol reagent. J. Biol. Chem. 193: 265-275.

20. Rastgoo L, Alemzadeh, A. 2011. Biochemical responses of Gouan (Aeluropuslittoralis) to heavy metals stress. Australian Journal of Crop ascience. 5(4):375-383. 
21. Singh A, Kumar CS, Agarwal A. 2013. Effect of lead and cadmium on aquatic plant Hydrillaverticillata Journal of Environmental Biology, 34: 1027-1031.

22. El-Khatib AA, Hegazy AK, Abo-El-KassemAM. 2014. Bioaccumulation Potential and Physiological Responses of Aquatic Macrophytes to PB Pollution.International Journal of Phytoremediation. 16:29-45.

23. Verma S, Dubey RS. 2003. Lead toxicity induces lipid peroxidation and alters the activities of antioxidant enzymes in growing rice plants. Plant Sci. 164:645-655.

24. Srivastava S, Mishra S, Dwivedi S, Baghel VS, Verma S, Tandon PK, Rai UN, Tripathi RD. 2005. Nickel phytoremediation potential of broad bean Viciafaba L. and its biochemical responses. Bull Environ Cotamin Toxicol.74:715-724.

25. Mishra S, Srivastava S, Tripathi R, Kumar R, Seth C, Gupta D. 2006. Lead detoxification by coontail (CeratophyllumdemersumL.) involves induction of phytochelatins and antioxidant system in response to its accumulation. Chemosphere. 65:1027-1039.

26. John P, Ahmad P, Gadgil K, Sharma S. 2009. Heavy metal toxicity: Effect on plant growth, biochemicalparameters and metal accumulation by Brassica junceaL. Int J Plant Prod. 3: 65-76.

27. Arun K. Shanker T. Cervantes C, Loza-Tavera H, Avudainayagam S. 2005. Chromium toxicity in plants, Environment International. 31: 739-753.

28. Mangal M. Agarwal M, Bhargava D. 2013. Effect of Cadmium and Zinc on growth and Biochemical Parameters of Selected Vegetables. Journal of Pharmacognosy and Phytochemistry. 2 (1): 106-114.

29. Huang GY, Wang YS, Sun CC, Dong JD, Sun ZX. 2010. The effect of multiple heavy metals on ascorbate, glutathione and related enzymes in two mangrove plant seedlings (KandeliacandelandBruguieragymnorrhiza). OceanologHydrobiolog Stud. 39(1):11-25.

30. Aly AA, Mohamed AA. 2012. The impact of copper ion on growth, thiol compounds and lipid peroxidation in two maize cultivars (Zea mays L.) grown in vitro. Austral J Crop Sci. 6(3):541-549.

31. Sytar O, Kumar A, Latowski D, Kuczynska P, Strzałka K, Prasad M N V. 2013. Heavy metal-induced oxidative damage, defense reactions, and detoxification mechanisms in plants. ActaPhysiol Plant.) 35:985-999.

32. Quartacci MF, Pinzino C, Sgherri CLM, DallaVecchia F, NavariIzzo F. 2000. Growth in excess copper induces changes in the lipid composition and fluidity of PSII-enriched membranes in wheat. PhysiologiaPlantarum. 108: 87-93.

33. Jemal F, Zarrouk M, Ghorbal MH. 2000. Effect of cadmium on lipid composition of pepper. Biochemical Society Transition. 28: 907-910.

34. Janicka R, Katarzyna K, Marek B, Grazyna K. 2008. Response of plasma membrane H+-ATPase to heavy metal stress in Cucumissativusroots. Journal of Experimental Botany. 59: 3721-3728.

35. Morsy AA, Salama KHA, Kamel HA. 2012. Effect of heavy metals on plasma membrane lipids and antioxidant enzymes of Zygophyllumspecies. Eurasia J Biosci. 6: 1-10.

36. Nouairi I, Ammar WB, Youssef NB, MiledDaoud DB, Ghorbel MH, Zarrouk M. 2006. Comparative study of cadmium effects on membrane lipid composition of Brassica juncea and Brassica napus "leaves". Plant Sci. 170: 511-519.

37. Ammar WB, Nouairi I, Zarrouk M, Jemal F. 2008. The effect of cadmium on lipid and fatty acid biosynthesis in tomato leaves. Biologia, 63(1): 86-93.

38. Dawes CJ, Guiry MD. 1992. Proximate constituents in the seagrasses, Zostera marina and $Z$. noltiiinIreland:Seasonal changes and the effect of blade removal. PSZN I: Mar. Ecol. 13:307-315.

39. John R, Ahmad P, Gadgil K, Sharma S. 2008. Effect of cadmium and lead on growth, biochemical parameters and uptake in LemnapolyrrhizaL. Plant Soil Environ. 54: 262-270.

40. Ahmad P, Sharma S, Srivastava PS. 2006. Differential physio-biochemical responses of high yielding varieties of Mulberry (Morusalba) under alkalinity (Na2CO3) stress in vitro. Physiol. Mol. Biol. Plants, 12: 5966.Nagajyoti PC, Lee KD, Sreekanth TVM. 2010. Heavy metals, occurrence and toxicity for plants: a review. Environ ChemLett 8:199-216. 